\title{
O desejo em jogo Uma abordagem a El juguete rabioso de Roberto Arlt
}

Gastón Cosentino (UFSC)

Ils jouent sans joujoux.

Charles Baudelaire

\begin{abstract}
Resumo
O presente artigo pretende por "em jogo" alguns aspectos do texto El juguete rabioso (1926) de Roberto Arlt que desmontariam alguns tecidos críticos urdidos em torno dele: o "fracasso" na vida e na literatura. O intuito de por em questão essa "arquitetura da falha" parte de que o texto, em particular, não recebe pacificamente essa determinação. Intuímos que pensar em termos de fracasso seria fazer funcionar a obra num sentido de anormalidade, como a desafinação de um instrumento que é preciso calibrar, a frustração de um projeto diagramado para o sucesso. Encontramos, por outra parte, que a armação crítica estaria sustentada na percepção do elemento "desejo" como uma falta a ser consumada, embora seja possível pensar o devir de Astier como o prazer de jogar um jogo sem procurar finalmente coisa alguma. Destas comoções surgem várias questões, entre elas: que aconteceria com a instalação de um desejo que a própria sedução destruiria mais tarde, aliás, para arrastar a confirmação de uma prática lúdica até as últimas consequências?

Palavras-chave: Literatura rio-platense; Teoria Literária; Filosofia; Teoria do Jogo.
\end{abstract}

\begin{abstract}
This article aims to put "in play" some aspects of the text by Roberto Arlt, El juguete rabioso (1926), to analyze some critical-woven tissues around it: the "failure" in life and in literature. In order to call into question this "architecture of failure" part of the text, in particular, does not receive peacefully this determination. Thinking in terms of failure would be running at work in one direction, abnormalities such as involved in an instrument that is need to calibrate, the frustration of a diagrammed for project success. We find, on the other hand, that the criticism would be sustained in the perception of the "desire" as a lack to be consummated, although it is possible to think the dévenir of Astier as the pleasure of playing a game without finally seeking anything. These commotions bring into view a number of issues, among them: what would happen with the installation of a desire that the seduction would destroy later, incidentally, to drag the confirmation of a playful practice up to the last consequences?
\end{abstract}

Keywords- River Plate Literature; Literary Theory; Philosophy; Game theory. 
${ }^{1}$ Bataille, Georges. La conjuración sagrada. In Acéphale: ensayos 1936-1939. Georges Bataille; Pierre Klossowski; Roger Caillois. Trad. Margarita Martínez. Buenos Aires: Caja negra, 2005.

\section{${ }^{2}$ Graciela Korolik, em sua investigação sobre os jogos} tradicionais argentinos, e que, sugestivamente, delimita entre o começo do século XX e os anos 1940, diz a respeito desse tempo que é uma data na qual o jogo experimenta uma mudança muito importante, provocada pelo desenvolvimento e o crescimento da indústria do brinquedo: o passo desde o brinquedo artesanal ao brinquedo mecânico ou eletrônico. Neste sentido, a referência lúdica que propõe Robeto Arlt poder-se-ia explicar a partir do que propõe Korolik, que coloca: “[...] La Torre en guardia (tiene) una coreografía y reglas algo más complicadas. Se elegían para jugarla al Rey, a los soldados y a dos niñas, que cumplían el papel de "torre", colocadas frente a frente y con las manos enlazadas. Una niña giraba alrededor de ellas y se suscitaba este diálogo cantado:

Niña: La Torre en guardia,/ la torre en guardia,/ la vengo a destruir.

Torre: Pues yo no temo,/ pues yo no temo,/ ni a ti ni a tus soldados.

Niña: Me voy a quejar,/ me voy a quejar,/ al gran Rey de Borgoña.

Torre: Pues vete a quejar,/ pues vete a quejar,/ al gran Rey de Borgoña.

$\mathrm{Al}$ recibir esta respuesta la niña se dirigía al Rey, que se encontraba con sus soldados y solicitaba ayuda:

Niña: Mi Rey, mi Príncipe,/ mi Rey, mi Príncipe,/ te vengo a suplicar.
"Se não é livre, a existência converte-se em vazia ou neutra, e se é livre é um jogo", professa Georges Bataille em um ensaio de 1936, na revista Acéphale ${ }^{1}$, dez anos após a publicação de El juguete rabioso. Estas associações animam nossa percepção de que o jogo operaria como um fio constitutivo que cruza a trama do desejo do personagem arltiano; desejo que, na sua liberdade de fluxo, traz aparelhado elementos do complexo que tentamos "por em jogo", a saber, a invenção e a traição.

Em sintonia com este pensamento, o jogo não funcionaria só como possibilidade de comoção da ordem ou da lógica proposta, mas também como parte fundamental de sua própria condição: "la palabra juego designa no solo la actividad específica que nombra, sino también la totalidad de las figuras de los símbolos o de los instrumentos necesarios a esa actividad o al funcionamiento de ese conjunto complejo" (CAILLOIS, 1986, p. 9). O jogo precisa espaço para se movimentar -pensemos em uma roda e seu eixo-; isso também é denominado jogo. Mas igualmente, o "jogo em falso" formaria parte de outro sedutor território: abrir-se-ia passo à transgressão ao próprio jogo e, consequentemente, na corroboração da prática lúdica, instalar-se-ia a fuga a outra parte, outro território. Esta lógica seria extensível ao trabalho com a literatura que faz Roberto Arlt na obra proposta. Por sua vez, dita movimentação trafegaria em harmonia com nossa ideia de análise enlaçada com o pressuposto de Roger Caillois (1986) quando coloca que o jogo só precisa do jogo mesmo para acontecer. Esta última asserção apresentaria a ideia de que o jogo não funciona como metáfora de alguma referência oculta no contexto ou texto. O jogo bosquejado operaria como uma atitude, uma poética possível:

[...] Cuando el negocio [ações delitivas] estaba en auge y las monedas eran reemplazadas por los sabrosos pesos, esperábamos a una tarde de lluvia y salíamos en automóvil. ¡Qué voluptuosidad entonces recorrer entre cortinas de agua las calles de la ciudad! Nos repantigábamos en los almohadones mullidos, encendíamos un cigarrillo, dejando atrás las gentes apuradas bajo la lluvia, nos imaginábamos que vivíamos en París, o en la brumosa Londres. Soñábamos en silencio, la sonrisa posada en el labio condescendiente.

Después, en una confitería lujosa, tomábamos chocolate con vainilla, y saciados regresábamos en el tren de la tarde, duplicadas las energías por la satisfacción del goce proporcionado al cuerpo voluptuoso, por el dinamismo de todo lo circundante que con sus rumores de hierro gritaba en nuestras orejas:

-iAdelante, adelante! (ARLT, 1993, p. 47) 
O esboço do esquema de El juguete rabioso poderia ser o seguinte: o personagem protagonista, Silvio Astier, põe seu desejo em jogo, joga seu desejo, espalha uma rede desejante sobre a proposta que lhe faz a vida cotidiana (outro jogo possível?), mas não procura levá-la a termo. Isso excederia a fronteira que expõe os limites de outro território. Para interferir, Silvio Astier constrói um tecido ficcional que aborda a vida desde uma dimensão lúdica. Acaso seja uma das poucas possibilidades de vincular um jogo incessante entre vida fática -território das necessidades- e fantasia-imaginação-sonho -território do desejo (AGAMBEN, 2005, p. 36); ou, simplesmente, ter um rol ativo nesse espaço de hostilidade chamado cidade. O personagem arltiano expõe seu desejo quando escolhe fazer sua intromissão na vida, jogá-la, expô-la à sorte, oferecer uma nova partida a partir da quebra das leis (ação que será adotada pela traição), na proposta de um novo jogo (espaço da invenção).

Escolhemos o jogo por seu poder questionador dos limites (HUIZINGA, 2008), sua pulsão associada à vontade de liberação, em um sentido de propor incessantemente outras regras; inventar para recriar o jogo. Assim, vemos como amostra algumas incrustações que na obra de Roberto Arlt são constantes infiltrações do jogo:

Desde afuera oíase el canto triste de una rueda de niños:

$$
\begin{gathered}
\text { La torre en guardia. } \\
\text { La torre en guardia. } \\
\text { La quiero conquistar'. (1993, p.77) }
\end{gathered}
$$

Nessas implicações lúdicas podem ser lidas ressonâncias de Charles Baudelaire, que no ensaio Morale du joujou ${ }^{3}$, publicado em Le Monde littéraire em 17 de abril de 1853, adverte, entre outras coisas pertinentes para nosso trabalho, uma íntima conexão entre quem brinca e seu brinquedo:

Tous les enfants parlent à leurs joujoux; les joujoux deviennent acteurs dans le grand drame de la vie, réduit par la chambre noire de leur petit cerveau. Les enfants témoignent par leurs jeux de leur grande faculté d'abstraction et de leur haute puissance imaginative. Ils jouent sans joujoux. (BAUDELAIRE, 1868, pp.141-142)

Neste sentido, as alusões ao jogo na obra arltiana só aparecem manifestadas por meio destas incrustações
Rey: Mi capitán, mi coronel,/¿qué es lo que me pides?

Niña: Lo que te pido, lo que te pido,/ es parte de tu guardia. Rey: Pues vaya mi guardia,/ pues vaya mi guardia,/ la torre a destruir.Los "Soldados" se lanzaban sobre la "torre" y trataban de destruirla separándole las manos, para lo cual se dividían a su vez en dos bandos que forcejeaban tomados de la cintura." In: KOROLIK, Graciela. Historia de Juegos Tradicionales de Argentina. Retablo de los juegos infantiles: Disponível em: http://www. acanomas.com/HistoriaJuegos-Tradicionales-deArgentina/1348/Retablo-de-losjuegos-infantiles.htm. Acesso em: 24 maio 2011.

${ }^{3}$ BAUDELAIRE, Charles. Morale du joujou. In: Oenvres Complètes (III) L'Art Romantique. Paris: Michel Lévy Frères, 1868. 
4 “JUEGO. El jugador porteño es un sórdido atesorador de sensaciones. Ninguno de ellos codicia dinero, aunque todos hablan de él como del objeto de sus devaneos. Todos los timberos tienen la certeza de que en el juego no harán fortuna.

Un carrerista sabe que al final de las ocho reuniones el Jockey Club les ha substraído más del cincuenta y cinco por ciento del dinero jugado, pero ellos no buscan dinero. "Hermano, dice uno. No hay emoción parecida al de una llegada en que los burros se acercan al disco apareados..." Hablan de sus emociones y no de sus peculios. (SCALABRINI ORTIZ, 1933, p. 154)

${ }^{5}$ Georges Bataille (1970, p. 28) escreve: "El hombre, a quien la conciencia de la muerte opone al animal, también se aleja de éste en la medida en que el erotismo sustituye el instinto ciego de los órganos por el juego voluntario, por el cálculo del placer."

${ }^{6} \mathrm{Na}$ Bíblia aparece o seguinte: "E disse Deus: Produza a terra relva, ervas que dêem semente, e árvores frutíferas que, segundo as suas espécies, dêem fruto que tenha em si a sua semente, sobre a terra. E assim foi. A terra, pois, produziu relva, ervas que davam semente segundo as suas espécies, e árvores que davam fruto que tinha em si a sua semente, segundo as suas espécies. E viu Deus que isso era bom. (Gênesis 1:11-12) [...] Disse-lhes mais: Eis que vos tenho dado todas as ervas que produzem semente, as quais se acham sobre a face de toda a terra, bem como todas as árvores em que há fruto que dê semente; ser-vos-ão para mantimento (Gênesis 1:29). Mais adiante, em (Mateus 13: 3-9) Jesus expõe por meio de uma parábola: "E falou-lhes muitas coisas por parábolas, específicas, por exemplificar, invenções excêntricas, brincar de roubar, brincar com a lei, etc; mas, quem brinca, o jogador, respira através do texto mesmo. Existe um boicote constante à "seriedade" da vida. Do mesmo modo, há uma coisa muito interessante que coloca Baudelaire na passagem citada anteriormente, a saber, que os brinquedos devém atores ou agentes dentro do grande drama da vida (BAUDELAIRE, 1868, p. 141). Esses atores seriam como uma espécie de extensão metamorfoseada do personagem que brinca? Acaso Silvio Astier poderia ser considerado, ao mesmo tempo, como uma expansão do seu próprio jogo? ; ou, simplesmente, uma transformação experimentada do seu jogo, o protagonista que devém brinquedo (raivoso), uma sabotagem na engrenagem da vida quotidiana. Maurice Blanchot aponta nessa direção:

[...] el juego de escritura en el que (el)lo, o bien participa siendo (al mismo tiempo) el producto o el don, o bien es la apuesta, la apuesta que, como tal, como jugador principal, juega, cambia, se desplaza y ocupa el lugar del cambio mismo, desplazamiento que carece de emplazamiento y del que todo emplazamiento carece. (1994, pp. 31-32)

A inquietude de analisar a obra desta perspectiva lúdica sustenta-se, além do mais, na possibilidade de prover seu próprio conjunto de ferramentas para indagar o texto. Entrar no texto e lê-lo na manipulação do próprio "brinquedo raivoso", experimentar suas mutações; conhecer o prazer de jogar ser um outro que experimenta Silvio Astier.

O périplo do protagonista de El juguete rabioso percorre o escrito em sintonia com uma oferenda lúdica não alinhada com a alternativa, o resto que os acontecimentos deparam-lhe aleatoriamente. $\mathrm{O}$ caminho de Silvio Astier não é paralelo ao que padece. Ele defasa o jogo mesmo, como um agente que interfere com sua obra o motor dessa alternância. A possibilidade de não ter e ter, ausência e presença, perder e ganhar, seriam uma mecânica elementar do jogo. Nada de buscas frenéticas de realização, senão intermitências. Já Huizinga, em outra passagem de seu texto, exprime alguns julgamentos que poderiam funcionar como enlace entre o desejo -como complexo- e o jogo ${ }^{4}$. De alguma maneira, a necessidade é excedida pela entidade do jogo:

No jogo existe alguma coisa "em jogo" que transcende as necessidades imediatas da vida e confere um sentido à ação. Todo jogo significa alguma coisa. [...] Seja qual for a maneira como o considerem, o simples fato de o jogo encerrar um sentido implica a presença de um elemento não material em sua própria essência. [...] O jogo se acha ligado a alguma coisa que não é o próprio jogo. (HUIZINGA, 2008, p. 3-4) 
Da mesma forma que acontece com a noção de desejo entendida como mera dinâmica produtiva - não como carência e procura dessa falta - o jogo, na mesma perspectiva, não leva a nada. Uma procura infrutuosa semelhante é descascar uma cebola à procura de alguma coisa. "Na cebola, de fato a casca é o caroço: não há mais hierarquia possível doravante entre o centro e a periferia" (DIDI-HUBERMAN, 2009, p. 25). Isso que se procura é possível que só exista em função de uma contingência, de um movimento aleatório e pouco antecipável.

Então, como se tocam o desejo e o jogo? É possível imaginar que o elemento conector entre o jogo e o desejo seja o pra$z^{5}{ }^{5}$. Segundo a tradição judaico-cristã a semente foi feita para engendrar, mas que aconteceria com a semente no pedregulho ${ }^{6}$ ? O prazer é visto como um desvio do caminho. $O$ prazer não gera uma estrutura organizada. O prazer é diabólico, usando o termo em sua acepção de dis-seminação, des-ordem, desunião, etc. Quer dizer que uma ação ou conduta que não tenha finalidade prática, sentido teleológico, seria condenável? Nesta perspectiva haveria uma forte vontade consecutiva que nulificaria o espaço do prazer, muitas vezes vinculado com o jogo. Por outra parte, em harmonia com o pensamento de Jean Duvignaud, e à pergunta que é brincar?, ele fala:

Las religiones monoteístas no aprecian en absoluto esa desviación lúdica de las funciones naturales [...] recuerdan a menudo con violencia, que la simiente está hecha para engendrar, no para desperdiciarse en vano. Por eso condenan el placer de los cuerpos [...]. (DUVIGNAUD, 1982, p. 32)

O filósofo Michel Onfray adverte não só a condenação praticada em torno à figura do desejo ao longo da "História" do pensamento, senão, o que seria mais inquietante, o motivo da lei como motor solapado e irresistível:

Platónicos y filósofos alejandrinos, Padres de la Iglesia, curas de todos los géneros y teóricos del Renacimiento, paladines del amor cortés y novelistas de los ciclos de caballería, petrarquistas y trovadores, todos estos idealistas, espiritualistas y demás dualistas profesan una teoría del deseo entendido como falta, dolor y condena $[\ldots]$ dejando tras de sí las huellas de un pensamiento obsesionado por la ley. (ONFRAY, 2002, p. 53)

Mais adiante, em referência ao Banquete platônico, Onfray dirá que o texto funda a desventura erótica ocidental clássica e que, além de definir o desejo como falta, a obra promove ideias a partir das quais organiza sua visão dominante do amor; um dualismo promotor da alma e negador do $\operatorname{corpo}^{7}$ (p. 53). De alguma maneira, a objurgatória do prazer e o corpo desencade- dizendo: Eis que o semeador saiu a semear e quando semeava, uma parte da semente caiu à beira do caminho, e vieram as aves e comeram. E outra parte caiu em lugares pedregosos, onde não havia muita terra: e logo nasceu, porque não tinha terra profunda; mas, saindo o sol, queimou-se e, por não ter raiz, secou-se. E outra caiu entre espinhos; e os espinhos cresceram e a sufocaram. Mas outra caiu em boa terra, e dava fruto, um a cem, outro a sessenta e outro a trinta por um. Quem tem ouvidos, ouça." In: Bíblia Sagrada. Tradução: João Ferreira de Almeida. Antigo e Novo Testamento. $2^{\mathrm{a}}$ ed. São Paulo: Sociedade Bíblica do Brasil, 1993.

${ }^{7}$ Las series de prohibiciones judías y musulmanas [...] son sólo comprensibles a través de la asociación sistemática del cuerpo con la impureza. Cuerpo sucio, desaseado, cuerpo infecto, cuerpo de materias abyectas, cuerpo libidinal, cuerpo maloliente, cuerpo de fluidos y líquidos, cuerpo infectado, cuerpo enfermo, cadáveres, cuerpos de perros y de mujeres, cuerpo de desechos, cuerpo de inmundicias, cuerpo sanguinolento, cuerpo hediondo, cuerpo sodomita, cuerpo estéril, cuerpo infecundo, cuerpo detestable...

(ONFRAY, 2006, p. 90) 
${ }^{8}$ In VIÑAS, David. "Arlt: robar y salir corriendo". AAVV. Ficciones argentinas. Antología de lecturas críticas. Compilación del Grupo de investigación de literatura argentina de la UBA. Buenos Aires, Norma, 2004, p.73-77.

${ }^{9}$ Não deixa de ser interessante a possibilidade de arriscar os contornos do roubo (em termos de apropriação) como prática literária, esboçando assim uma poética da escrita, neste caso específico, a partir de uma sorte de "cleptoescritura", a partir do conceito de "cleptomnese" ensaiado por Noé Jitrik, no seu ensaio Intertextualidady cleptomnesis: "La escritura [...] procede por cleptomnesis, descansa sobre un robo a la memoria, se realiza con lo que ya se realizó y está remitido, olvidado y, por eso, aparece como siempre nuevo aunque en algún momento lo fue; por eso, también, la sensación de glorioso triunfo cuando la escritura se realiza en imágenes que parecen nuevas $y$, al mismo tiempo, una reminiscente angustia, un más acá de lo nuevo, lo que reaparece o bien se le debe a alguien a quien se le adquirió esa imagen; otros textos, otros escritos; que entró en una memoria que la procesó, la alteró, la transformó pero no la destruyó. In: Luvina, Revista Literaria de la Universidad de Guadalajara. Número 52, ano 2008. <http://luvina.com.mx/ foros $/$ index.php?option $=$ com content\&task $=$ view\&id $=98 \&$ Ite mid=38>. Acessado em $20 \mathrm{de}$ julho de 2011.

${ }^{10}$ No texto El erotismo, Georges Bataille agrega que "la desnudez, opuesta al estado normal, tiene ciertamente el sentido de una negación. La mujer desnuda está cerca del momento de la fusión; ella la anuncia con su desnudez. Pero el objeto que ella es, aun ará, entre outras coisas, a condenação ao jogo, prática afastada deliberadamente da esfera das responsabilidades sociais por seu caráter estéril e, especialmente, por sua "improdutividade".

De modo análogo, o percurso de Silvio Astier se veria afetado invariavelmente por um corte produtivo, já que "lo que consigue siempre se le escapa, de suerte que [...] nunca ni está falto de recursos ni es rico" (PLATÃO, 1986, apud LYOTARD, 1998, p. 84).

\section{III}

Do mesmo modo que David Viñas propõe que na escrita de Roberto Arlt "robar y escribir se superponen, [...] son análogos" (2004, pp. 73-74), possivelmente desde um lugar da escrita como subtração ${ }^{9}$ de um espaço que materializaria o jogo, nós propomos que desejo, invenção, traição -urdidos pelo fio lúdico- operam em constelação, de modo semelhante, bosquejando um mapa imaginável de escrita e/ou leitura. Assim também, a superposição da que fala Viñas funcionaria na ordem da fusão, já não como calco - questão que levaria a uma fidelidade impossível na obra-, senão como roubo que marca seu rastro em sua des-legitimação constante, uma escrita que furtaria os espaços da lei. Nessa articulação da esfera do roubo e o âmbito da literatura, o crítico Blas Matamoro expõe que "Arlt [...] se nutrió de las letras que pudo robar, como los chicos de su novela. [...] Propone un estatuto de escritor ladrón [...] sin someterse a una disciplina escolar y aprenderse la cartilla o el Canon [...]." (2003, s.p.)

Seria suscetível de fracasso -agora funcionando o termo negativamente-, por outra parte, uma leitura que pretendesse resolver com as regras ou leis da vida cotidiana (extraliterária) aquilo que simplesmente seria posto em jogo na literatura. Posto que "escrever é um caso de devir, sempre inacabado, sempre em via de fazer-se, e que extravasa qualquer matéria vivível ou vivida" (DELEUZE, 2004, p. 11).

Outros traços que operacionalizam cortes produtivos estariam, por exemplo, em indícios eloquentes como o próprio texto sugerindo que a semi-nudez seduziria de modo mais intenso que a nudez ${ }^{10}$. A presença da ausência que manifestara Lyotard (1998) na sua conferência a respeito do desejo? Poderíamos pensar com Georges Bataille, que Astier por meio da fantasia consegue questionar os limites propostos por um desejo entendido como "falta-busca-fim"; o excesso radicaria em diferir o contato, em extremar o prazer: 
La desnudez arruina el decoro que nos proporcionan los vestidos. Pero en cuanto nos adentramos en la vía del desorden voluptuoso, nada nos detiene. La destrucción o la traición se asocian a veces al aumento del exceso genético. A la desnudez añadimos la extrañeza de los cuerpos semivestidos, cuyos ropajes no hacen sino subrayar el desorden del cuerpo, que de tal guisa se vuelve más desordenado, más desnudo. (BATAILLE, 1970, p. 142)

Por conseguinte, no texto arltiano o que erotiza não seria a consumação, senão o contrário: o que torna erótico seria o avesso dos fatos, um paradoxal momento que se descobre se cobrindo: disfarçando e desvendando; um exercício de simulação anunciador de um simulacro ainda maior, sempre adiado. "El placer consiste en ser otro o en hacerse pasar por otro. Pero como se trata de un juego, en esencia se trata de engañar al espectador" (CAILLOIS, 1986, p. 55). A paralisação da presumível totalidade por uma sugestão funcionaria para não esgotar a condição erótica. Reconstruir -fazer desmontagem e montagem- (DIDI-HUBERMAN, 2006), uma vestidura após sua nudez ${ }^{11}$ é um gesto desafiante para os sentidos. Espacialização do tempo erótico para introduzir um jogo. Nesta passagem, o texto de Arlt desconstrói a lógica tradicional do desejo:

Yo me dejo estar. Pienso, no, no pienso, mejor dicho, recibo de mi adentro una nostalgia dulce, un sufrimiento más dulce que una incertidumbre de amor. Y recuerdo a la mujer que me ha dado un beso de propina.

Estoy colmado de imprecisos deseos, de una vaguedad que es como neblina, y adentrándose en todo mi ser, lo torna casi aéreo, impersonal y alado. Por momentos el recuerdo de su fragancia, de la blancura de su pecho me atraviesa unánime, y sé que si me encontrara otra vez junto a ella desfallecería de amor; pienso que no me importaría pensar que ha sido poseída por muchos hombres y que si me encontrara otra vez junto a ella, en esa misma sala azul, yo me arrodillaría en la alfombra y pondría la cabeza sobre su regazo, y por el júbilo de poseerla y amarla haría las cosas más ignominiosas y las cosas más dulces.

$\mathrm{Y}$ a medida que se destrenza mi deseo, reconstruyo los vestidos con que la cortesana se embellecerá, los sombreros armoniosos con que se cubrirá para ser más seductora, y la imagino junto a su lecho, en una semidesnudez más terrible que el desnudo. (ARLT, 1993, pp. 106-107) siendo el signo de su contrario, de la negación del objeto, es aún un objeto. Esa es la desnudez de un ser definido, aunque anuncie el instante en que su orgullo caerá en el vertedero indistinto de la convulsión erótica. De entrada, esa desnudez es la revelación de la belleza posible y del encanto individual. Es, en una palabra, la diferencia objetiva, el valor de un objeto comparable a otros objetos." (1997, p. 137)

11 "A nudez nunca eliminará a sedução, pois instantaneamente torna-se outra coisa [...] um outro jogo que a ultrapassa [...]. Todos os nossos signos hoje parecem concorrer, como o corpo na nudez, como o sentido na verdade, a uma objetividade definitiva [...]" (BAUDRILLARD, 2006, p. 53) estritos ou de realidade cotidiana. Conforme condição do pró- 
prio jogo, ele não precisaria do aspecto teleológico. A capacidade, por outra parte, metamórfica da imagem "brinquedo raivoso" explicaria, em parte, a vigência e a renovação dos sentidos cristalizados. Estranho paradoxo oferece a imagem do título, no sentido que um brinquedo, em termos tradicionais, completaria, de alguma maneira, sua significação na própria manipulação dele. O que Arlt promove com o título de sua obra, e opera através da performance de Silvio Astier, seria fazer agir, em palavras de Didi-Huberman, "una criatura del paso y del deseo, del movimiento y el consumo." (2007, p. 20). A propósito desta abordagem, o filósofo francês descreve a afinidade entre o desejo e sua "imagen borboleta" quando expressa que " [...] esa cosita que revolotea y nos cautiva, es reconocida y tomada por criatura del deseo. A menudo, Eros es representado con una mariposa en la mano" (2007, p. 25). Mais adiante, escreve Didi-Huberman:

El ser que mariposea hace al menos dos cosas: para empezar, palpita y se agita convulsivamente, su cuerpo va y viene sobre sí mismo, como en un baile erótico o en un trance. Luego, el ser que mariposea yerra y se agita al tuntun, arrasando su cuerpo de aquí para allá en una especie de exploración inquieta, en una especie de búsqueda de la que decididamente ignora cuál es el objetivo final. En esta danza hay algo de la inestabilidad fundamental del ser, una huida de ideas, un poder absoluto de la libre asociación, un mandato del salto, una ruptura constante de las soluciones de continuidad”. (Didi-Huberman, 2009, p. 27)

Assim, o percurso do Silvio Astier seria uma espécie de "borboleteio", lepidóptero de cidade - que até poderia ser cinza como uma bruxa ou uma traça-, no sentido que seu vagar, possivelmente, não procure outra coisa que deixar acontecer seu desejo. Acrescenta Didi-Huberman:

Es por ello que de la mariposa o del mariposeador se dice con malicia que lo derrochan todo sin fundar jamás nada sólido. [...] La mariposa/variante/alternante caracteriza una de las pasiones humanas que ninguna ley moral debería restringir. [...] Mariposeo, ese vagabundeo aéreo desde el punto de vista de una verdadera estrategia del deseo concebido como utopía política [...] Así pues, mariposear: bailar con el propio deseo hacia y contra todo. Suscitar, por aquí y por allá, una aparición posible. $(2007$, p. 28)

A união instável entre o brinquedo e a raiva contamina o desejo, faz que a alternância injeção/rejeição movimente as peças deste aparelho lúdico arltiano; uma economia lépida e desejante que cartografaria o percurso de Silvio Astier como começo e fim da literatura como meio -o protagonista é escritor-, uma sobrevida, um desejo reconfirmado. O que revelaria com energia a inclinação de Silvio Astier pela escritura -além de 
suas leituras explicitadas e sua afeição geral pela literatura-é um resto $^{12}$. Trata-se de um capítulo intitulado El poeta parroquial que Roberto Arlt decidiu tirar da edição de El juguete rabioso de 1926, no qual o protagonista explicita seu desempenho literário em uma visita a um reconhecido poeta do bairro de Flores:

-Y ustedes, ¿no escriben? [poeta]

—El señor — dijo Juan.

— ¿Prosa o verso?

-Prosa.

- Me alegro, me alegro... Si necesita alguna recomendación...

Tráigame algo para leer... Si gustan visitarme los domingos a la mañana, haríamos un paseíto hasta el Parque Olivera. Yo acostumbro a escribir allí. ¡Ayuda tanto la naturaleza! —Cómo no! Gracias; vamos a aprovechar su invitación. (ARLT, 1993, pp. 203-204)

Daí que a ilusão funciona como aquela que mantém viva a chama do desejo, a ilusão-inludere ${ }^{13}$, a posta em jogo da vida: "la mariposa no desaparece [...] en la llama de una vela, sino para hacer de su ausencia un largo transporte psíquico, una obsesión, una supervivencia, un deseo reconfigurado" (DIDI-HUBERMAN, 2007, p. 29).

Como será possível, no texto arltiano a invenção/re-invenção no jogo? Novamente, o proteico texto $A$ imagem borboleta proporciona-nos uma passagem que poderia servir como chave de leitura. Didi-Huberman (2007, p. 59) expressa, a propósito de uma visão de Walter Benjamin, que "quería convertirse en una imago para que la imago le permitiera acercarse antes de que todo retornara a su lugar con el gesto fatal de la captura, por el cual el cazador volvería a ser humano y la víctima animal". Em nosso parecer há uma instância na qual é possível habitar o desejo (a presença-ausência). Este será, quiçá, o espaço do devir-animal deleuzeano, a intervenção do brinquedo raivoso; o que não deixaria de acontecer é a pulsão lúdica que contamina o texto. Lemos numa das Passagens de Walter Benjamin:

"Afirmo que a paixão pelo jogo é a mais nobre das paixões, porque ela comporta todas as outras. Uma sequência de jogadas felizes me proporciona mais prazer do que um homem que não joga poderia ter em vários anos. Você pensa que no ouro que me chega eu só vejo lucro? [...] Vejo nele as alegrias que ele proporciona e saboreio-as verdadeiramente. Essas alegrias, vivas e ardentes como relâmpagos, são rápidas demais para me entediar. Tenho cem vidas numa só." (GOURDON, 1860, s.p., apud BENJAMIN, 2006, p. 536)
${ }^{12}$ Este texto fue publicado por Roberto Arlt en la revista Proa, en marzo de 1925, como anticipo de "El juguete rabioso". Cuando la novela apareció al año siguiente, el capítulo había sido excluido. (PIGLIA, 1993, p. 199)

${ }^{13}$ Neste aspecto Edgardo Berg coloca o seguinte: "Sus textos son realistas en el sentido que intentan mostrar el funcionamiento social de la ilusión y sus textos son verdaderos tratados del hacer creer. La imitación, la copia no es ya entendida como mímesis sino como fraude, como el lugar de la enunciación donde se encuentra el régimen económico y el régimen del deseo. No hay nada real representado, sino la puesta en escena de la máquina retórica que alimenta la sociedad. Sus textos captan el núcleo secreto del mundo moderno: el impacto de las ficciones sociales, la manipulación de la creencia, la fabricación de los hechos." (2006, s.p.)

${ }^{14}$ Jean Baudrillard diz em um trabalho intitulado El sistema de los objetos: "Vértigo de la ilusión de las energías encadenadas en los símbolos mismos de dominio del mundo que son los objetos técnicos. Esta postulación contradictoria de vencer a la fatalidad y de provocarla es lo que se refleja en el orden económico de producción, el cual, aunque produzca sin cesar, no puede producir sino objetos fragilizados, disfuncionales en parte, condenados a una muerte rápida, que de tal manera laboran por su destrucción al mismo tiempo que por su producción.” (1969, p. 150) 


\section{Alea: "Es este el nombre del} juego de dados en latín. Lo tomo aquí para designar, en oposición exacta al agon, todos los juegos basados en una decisión que no depende del jugador, sobre la cual no podría éste tener la menor influencia y en que, por consiguiente, se trata mucho menos de vencer al adversario que de imponerse al destino." (CAILLOIS, 1986, p. 48).

${ }^{18}$ Maurice Blanchot ensaia o paradoxo da existência da sorte nas seguintes palavras: "«Tengo suerte.» Fórmula tan fuerte como descarada, pues la suerte desposee y desapropia. Lo cual, ijugador que pretendes hablar en nombre del juego!, vendría a decir: poseo lo que desposee, siendo la relación de desposesión. Lo que viene a decir que no hay suerte para la suerte y que la única suerte residiría en esa relación anónima que, a su vez, no podría ser llamada suerte o sólo aquella suerte que no acaece, y con la que lo neutro jugaría dejando que ésta se burle de él." (1994, p. 56)

${ }^{19}$ Por outra parte o batacazo tem conotações musicais, mais especificamente percussivas. Diz o Dicionário de Percussão: "Termo espanhol. Outro nome para o golpe dado com a 'mão' aberta no 'atabaque', chamado na cultura Ioruba de 'banto mbatá' (Cuba, Am. Central)". (FRUNGILLO, 2002, p. 34)
Se há um objeto deslumbrante e popularíssimo que está cruzado pela ciência, a arte e o jogo - provavelmente a metade do caminho do denominado "brinquedo científico"14 por Baudelaire - sem sombra de dúvidas é o caleidoscópio ${ }^{15}$. O caótico kalos arltiano tentaria se construir a força de assaltos, deslocamentos, rupturas. A organização anárquica de uma soma de fracassos inventaria uma imagem possível do mundo arltiano. O olhar de Silvio Astier manipula o mundo urbano na procura de uma imagem que sempre se apresenta como mutável. O que interessa no caleidoscópio é a próxima imagem, a presente manifesta-se ininterruptamente, de modo difuso, interpelada pelos fantasmas da imagem precedente e a futura - na verdade a imagem presente para Silvio Astier está sempre diferida - como no caleidoscópio. Tratar-se-ia, acaso, de uma constante tentativa de imagem dialética em termos benjaminianos? Ou melhor, o artifício da imagem do caleidoscópio arltiano: que funciona como desejo (que movimenta o aparelho); que obra como invenção (a combinação motivada de peças) e que opera como contínua traição (nenhuma imagem é suficiente). Na destruição do jogo anterior assentam-se as condições do próximo jogo, em uma repetição - no caso própria da circularidade do caleidoscópio inesgotável. Tudo se sutura com o fio do jogo: o caleidoscópio é jogo. Diz por sua parte Michele Aynesworth a respeito da mutabilidade continua que percebemos na primeira novela de Arlt:

\begin{abstract}
Mad Toy presents a kaleidoscope of color, tone, and mood, now lyrical, now ironic, now earthy, now reportorial, now heroic, now hardboiled. Language varies from the relatively cultured idiom of the narrator to the dialects and street slang of the novel's many colorful characters, including Silvio, the narrator's younger self. (AYNESWORTH, 2002, p. 3)
\end{abstract}

A partir destas considerações, a figura do "batacazo 16 ", que em termos de Roger Caillois formaria parte da sub-categoria do jogo denominada alea $a^{17}$, é uma sorte ${ }^{18}$ de golpe inesperado muitas vezes associado ao êxito - que traria a fortuna e com ela a mudança da vida do jogador. De acordo com nossas conceituações a figura do "batacazo" além de manifestar o tradicional golpe $^{19}$ de sorte - sempre associado à dimensão do dinheiro - poderia ser resignificada e jogada como golpe de reconfiguração do espaço e das suas possibilidades no espaço literário, porque, como enuncia Blanchot (1994, pp. 55-56): "la suerte no acaece más que por el juego. Y el juego no está destinado a nadie en particular." Voltemos agora à lógica do caleidoscópio - acaso terá lógica? O "batacazo" ${ }^{20}$ funcionaria como fortuna 
que movimenta o caleidoscópio arltiano de um modo intempestivo e com traços sempre arrebatadores. É importante dizer que nossa crítica não está à procura de alguma configuração exata ou oculta entre as partes movimentadas, simplesmente no momento em que restos combinam-se de maneira aleatória a partir de um espaço delimitado, com peças postas em jogo e que são, por sua vez, "o jogo". Por outra parte, dito brinquedo configura-se no movimento, no trânsito, na perduração que está menos conectada com a fascinação da disposição caótica dos restos, do que com a impossibilidade de outorgar ao operador da máquina uma imagem primordial ou concluída. O que não cessa de funcionar é uma fascinação do movimento análoga à imagem-borboleta que propõe Didi-Huberman: intuição que se dá em voo, em um abrir e fechar de asas, sempre preterindo uma imagem pretensamente total; apenas um intervalo que convida a continuar na contemplação. Imagem que - isso é extensível ao texto, claro - morre na pretensão de fixá-la para ver-ler. No caso do brinquedo caleidoscópico, baste investi-lo de algum tom de seriedade, correção ou moralismo para encontrarmos com umas quantas contas desluzidas e um triângulo de espelhos capaz só de multiplicar suas arestas vazias.

Por outra parte, um aspecto sedutor do objeto lúdico indagado é que as peças do jogo são menos do que aparentam ser, embora postas em jogo já não seja possível distinguir entre “originais" e cópias. Há uma sorte de pacto entre observador e objeto, na acomodação dos espelhos, uma lógica, novamente, extensível à leitura e os leitores, que - como em nosso caso particular - co-operam um "batacazo" no texto e re-configuram as peças dispostas pelo narrador na procura de sua fortuna leitora ou crítica, ou melhor, de recepção.

Em La imagen-malicia ${ }^{21}$, Didi-Huberman resgata e põe em funcionamento as consequências do caleidoscópio enquanto prótese de leitura, o agir da criança a respeito do jogo através de Baudelaire com as teorizações de Walter Benjamin para ensaiar uma teoria capaz de articular e revisar a história, a imagem e o tempo.

Desta maneira, tanto neste "brinquedo científico", quanto em uma obra literária ou uma leitura dessa obra, não existe uma imagem originária, no sentido de fundação, começo ou pureza. Antes de levar o aparelho ao olho, já há uma imagem. Uma imagem ininteligível por inacessível. No momento em que o observador toma o aparelho, a imagem já mudou. A imagem presumivelmente presente é uma re-combinação (remontagem) de um resto jamais acessado.
${ }^{20}$ Diz David Viñas em relação ao motivo do "batacazo" em Arlt: "hay otra lectura posible sobre el tema de los inventos que va más allá de seducir o deslumbrar a quien sea; y es la idea del batacazo, que también es característica de la clase media argentina. ¿Cuántos millones de personas juegan y siguen jugando a la lotería? Mi tía me decía siempre: «Este año ganamos la grande»; y era la típica mujer de clase media casada con un artesano. El batacazo resume la idea de «hacer la América»." (VIÑAS, 1998, p. 80)

${ }^{21}$ Ver o capítulo de Georges Didi-Huberman. Caleidoscopio e rompecabezas: el tiempo se lanza como un bretzel... In: Ante el tiempo. Historia del arte y anacronismo de las imágenes. Buenos Aires: Adriana Hidalgo, 2006, pp. 181-213. 


\section{Referências}

AGAMBEN, Giorgio. Infância e história. Destruição da experiência e origem da história. Belo Horizonte: UFMG, 2005.

ARLT, Roberto. El juguete rabioso. Buenos Aires: Espasa Calpe, 1993.

BATAILLE, Georges. Breve historia del erotismo. Montevideo: El caldén, 1970. . El Erotismo. Barcelona: Tusquets, 1997. La conjuración sagrada: ensayos 1929-1939. Buenos Aires: Adriana Hidalgo, 2003. . Acéphale: ensayos 1936-1939. Georges Bataille; Pierre Klossowski; Roger Caillois. Trad. Margarita Martínez. Buenos Aires: Caja negra, 2005.

BAUDELAIRE, Charles. Morale du joujou. In: Oeuvres Complètes (III) L'Art Romantique. Paris: Michel Lévy Frères, 1868.

BAUDRILLARD, Jean. Da sedução. $6^{\text {a }}$ ed. São Paulo: Papirus, 2006.

BENJAMIN, Walter. Passagens. Trad. Irene Aron, Cleonice P. B. Mourão. Belo Horizonte: UFMG; São Paulo: Imprensa Oficial do Estado de São Paulo, 2006.

BERG, Edgardo H. Roberto Arlt: un autor en escena. In: Espéculo. Revista de estudios literarios. Universidad Complutense de Madrid. 2006. \# 33. <www.ucm.es/info/ especulo/numero33/paparlt.html>

Bíblia Sagrada. Trad. João F. de Almeida. Antigo e Novo Testamento. $2^{a}$ ed. São Paulo: Sociedade Bíblica do Brasil, 1993.

CAILLOIS, Roger. Los juegos y los hombres: la máscara y el vértigo. México: Fondo de Cultura Económica, 1986.

DELEUZE, Gilles. A literatura e a vida. São Paulo: Editora 34, 2004.

DIDI-HUBERMAN, Georges. Ante el tiempo. Historia del arte y anacronismo de las imágenes. Buenos Aires: Adriana Hidalgo, 2006. . La imagen mariposa. Barcelona: El mudito \& Co, 2007. Ser crânio. Lugar, contato, pensamento, escultura.

Trad. Vera C. Nova. Belo Horizonte: Com arte, 2009. 
DUVIGNAUD, Jean. El juego del juego. México, Fondo de Cultura Económica, 1982.

HUIZINGA, Johan. Homo ludens. São Paulo: Perspectiva, 2008 JITRIK, Noé. Intertextualidady cleptomnesis. In: Luvina, Revista Literaria de la Universidad de Guadalajara. Número 52, ano 2008. <http://luvina.com.mx/foros/index.php?option=com_ content\&task $=$ view\&id $=98 \&$ Itemid $=38>$

KOROLIK, Graciela. Historia de Juegos Tradicionales de Argentina. Retablo de los juegos infantiles: <http:/ / www.acanomas.com/ Historia-Juegos-Tradicionales-de-Argentina/1348/Retablo-delos-juegos-infantiles.htm>

LYOTARD, François. ¿Por qué filosofar?: Cuatro Conferencias. Barcelona: Altaya, 1994.

MATAMORO, Blas. La juguetería rabiosa de Roberto Arlt. Biblioteca Virtual Miguel de Cervantes: Alicante, 2003. <http:// cervantesvirtual.com/FichaObra. html?Ref $=$ http $\% 3 \% 2 \mathrm{~F} \% 2 \mathrm{~F} \% 2 \mathrm{Fcvc}$.cervantes. es $\%$ Factcult $\%$ Farlt $\% 2$ introduccion.htm\&portal $=0>$

ONFRAY, Michel. Teoría del cuerpo enamorado: Por una erótica solar. Valencia: Pretextos, 2002. - Tratado de ateología. Física de la metafísica. Trad. Luz Freiré. Barcelona: Anagrama, 2006.

SCALABRINI ORTIZ, Raúl. El hombre que está solo y espera. Buenos Aires: Librerías Anaconda, 1933.

VIÑAS, David. “Arlt: robar y salir corriendo”. AAVV. Ficciones argentinas. Antología de lecturas críticas. Compilación del Grupo de investigación de literatura argentina de la UBA. Buenos Aires: Norma, 2004. 